\title{
ANALISIS DAMPAK PENGGUNAAN E-TOLL CARD TERHADAP EFEKTIVITAS LAYANAN DI GERBANG TOL MAKASSAR
}

\author{
Hasdiana $S^{* 1}$,Ibriati Kartika Alimuddin ${ }^{2}$ \\ Universitas Muslim Maros, Jl. Pamalekang Je'ne Kab. Maros \\ Fakultas Ekonomi dan Bisnis \\ E-mail: ${ }^{* 1}$ hasdiana@umma.ac.id, ${ }^{2}$ ibhiekartika@yahoo.co.id
}

\begin{abstract}
Abstrak
Tujuan penelitian ini adalah untuk mengetahui dampak yang ditimbulkan atas penggunaan e-Toll card terhadap efektivitas layanan di gerbang toll Makassar yang merupakan salah satu program pemerintah dalam bentuk layanan pembayaran toll secara. Adapun yang menjadi target khusus yang ingin dicapai dalam penelitian ini adalah untuk mengetahui tingkat efektivitas pelayanan di gerbang tol yang ada di Makassar dengan menggunakan etoll card. Metode yang dipakai dalam penelitian ini adalah deskriptif atau metode yang menjelaskan pengaruh antara variabel independent yang diuji terhadap variabel dependen. Metode pengambilan sampel dalam penelitian ini dengan menggunakan Teknik purposive sampling dengan menentukan kriteria pengguna jalan tol dengan menggunakan e-toll card. Alat analisis yang digunakan yaitu regresi sederhana. Jenis data yang digunakan adalah data primer dan sekunder, Sementara teknik pengambilan data menggunakan wawancara dan penyebaran kuisioner. Hasil yang ingin dicapai dalam penelitian ini adalah untuk mengetahui pengaruh penggunaan e-toll card terhadap efektivitas layanan di gerbang toll Makassar.
\end{abstract}

Kata Kunci :E-toll card, Efektivitas layanan.

\begin{abstract}
The purpose of this study is to determine the impact caused by the use of e-Toll cards on the effectiveness of services at the Makassar toll gate, which is one of the government programs in the form of electronic toll payment services. As for the specific target to be achieved in this research is to determine the level of effectiveness of services at the toll gate in Makassar by using e-toll card. The method used in this study is descriptive or a method that explains the effect of the independent variables tested on the dependent variable. The sampling method in this study used a purposive sampling technique by determining the criteria for toll road users by using e-toll cards. The analytical tool used is simple regression. The type of data used is primary and secondary data. While data collection techniques using interviews and questionnaires. The results to be achieved in this study are to determine the effect of the use of e-toll cards on the effectiveness of services at the Makassar toll gate.
\end{abstract}

Keywords : E-toll cards, effectiveness of services

\section{PENDAHULUAN}

Di era disrupsion ini dimana banyak hal yang berubah dengan begitu cepat, tak terkecuali dibidang perekonomian. Sistem pembayaran pun mengalamai transformasi mulai dari cara tradisional dan kini menjadi lebih modern. Untuk mewujudkan harapan bangsa tentang adanya masyarakat non tunai kini Bank Indonesia terus meningkatkan elektronifikasi transaksi pembayaran dan peningkatan infrastruktur sistem pembayarannya. Dengan menggunakan jasa perbankan, 
kini pemerintah menetapkan sistem pembayaran di bidang layanan transportasi. Tak terkecuali di Makassar, salah satunya pada transaksi di beberapa gerbang tol yang ada di Makassar.

Upaya pemerintah Makassar dalam memaksimalkan penggunaan jalur bebas hambatan atau jalan tol sebagai altematif dalam meminimalisir kemacetan, akan tetapi hal ini tetap saja tidak berjalan secara maksimal. Masalah yang terjadi adalah kurangnya kesadaran pengguna layanan jalan tol, dimana telah adanya pemberitahuan bahwa bayarlah tarif tol dengan uang pas sesuai dengan tarif yang telah ditentukan, akan tetapi para pengguna layanan masih banyak yang tidak menghiraukan dan membayar dengan uang lebih. Sehingga petugas membutuhkan waktu untuk mengembalikan investasi pengendara.

Masalah tersebut membuat salah satu lembaga yang bergerak dalam bidang pengelola jalan tol yaitu PT. Bosowa Marga Nusantara Makassar melakukan peningkatan pelayanan dengan menerapkan sistem pembayaran non tunai atau elektoronik money toll ( $e$ Toll) yang bekerjasama dengan lembaga perbankan dalam untuk menerbitkan $e$ toll card. Penggunaan e-toll card ini diterapkan dengan berbagai tujuan yaitu mempercepat layanan transaksi, meminimalisir antrian, dan meneyelaraskan program pemerintah GNNT (Gerakan Nasional Non Tunai). Kartu ini diharapkan dapat membantu mengurangi waktu antrian pembayaran tol, yang biasanya durasi transaksi sekitar $6-7$ detik menjadi hanya $3-4$ detik. Akan tetapi,transaksi dengan menggunakan e-toll card barusekitar 12\% (Sabrina OS : 2015)

Bank Indonesia sebagai leading dalam hal penggunaan e-payment pada sektor jalan tol melakukan berbagai kegiatan sosialiasi dengan melibatkan beberapa stakeholder, user secara langsung serta PT Bosowa Marga Nusantara sebagai badan usaha jalan tol. Tahapan sosialisasi ini diawali pada akhir tahun 2017 dengan system ceremony. Fase awal ini hanya mencapai target sekita 52-58\%. BPJT atau Badan Pengatur Jalan Tol sebagai regulator Kementrian Pekerjaan Umum dan Perumahan Rakyat (PUPERA) terus mendesak dilakukan implementasi epayment pada semua unit tol yang ada, karna berdasarkan data yang ada bahwa Makassar merupakan jalan tol 3 terbawah yang belum implemantasi unit. Fase kedua dilakukan secara langsung dengan meningkatkan sosialisasi dengan menggunakan berbagai media seperti, baliho, templete, media social, media cetak, media elektronik sampai menggunakan ikonikon unik disetiap gerbang tol. Fase kedua ini melibatkan beberapa user seperti lembaga pemerintahan maupun swasta hingga pihak Gojek dan Grab. Dan fase kedua ini di peroleh data implemntasi e-payment di gerbang tol sebesar 100\% pada November 2018.

Sebelum transaksi elektronik diwajibkan, para pengguna jalan tol yang menggunakan e-toll card dapat menggunakannya di Gerbang Tol Otomatis (GTO) dengan mudah dan cepat tanpa harus mengantre dibandingkan dengan pengguna jalan tol lain yang tidak memiliki e-toll card harus melakukan pembayaran tol dengan uang tunai yang dilayani oleh petugas pengumpul tol (Wachidatus \& Novi M, 2018)

Layanan e-toll card di Kota Makassar pada penerapannya dirasa memiliki tujuan yang dianggap sangat baik dalam meminimalisir kemacetan di gerbang tol. Namun, perubahan layanan ini tidak sepenuhnya berjalan sesuai dengan tujuan yang telah ditentukan. Hal tersebut dibuktikan dengan 
argumen dari beberapa pengguna layanan e-toll card. Berkaitan dengan hal tersebut maka pada kesempatan kali ini penulis melakukan penelitian terkait dalam hal penerapan e-toll cardoleh PT. Bosowa Marga Nusantara Makassar dengan judul " Analisis Dampak Penggunaan E-Toll Card terhadap Efektivitas Pelayanan di Gerbang Toll Makassar"

\section{Rumusan Masalah}

Dengan adanya e-toll card yang ditetapkan sebagai alat pembayaran pada beberapa gerbang toll yang ada di Makassar, diharapkan dapat meningkatkan kinerja pemerintahan yang bekerjasama dengan lembaga yaitu PTBosowa Marga Nusantara sebagai pengelola jalan tol untuk memberikan pelayanan yang baik ke masyarakat. Untuk itu, maka rumusan masalah dalam penelitian ini adalah bagaimana dampak yang ditimbulkan dengan penggunaan e-toll card terhadap efektivitas pelayanan di gerbang toll Makassar

\section{Tujuan Khusus Penelitian}

Adapun yang menjadi tujuan khusus dalam penelitian ini adalah untuk mengetahui pengaruh penggunaan e-toll card terhadap tingkat efektivitas pelayanan di gerbang toll Makassar.

\section{Pengertian Jalan Tol}

Jalan tol adalah suatu lintas jalan yang merupakan alternatif dari lintas jalan umum yang ada, mempunyai spesifikasi jalan bebas hambatan dan jalan tol hanya diperuntukkan bagi pemakai jalan yang menggunakan kendaraan bermotor roda 4 atau lebih dengan membayar tol (UU No 13 tahun 1980). Pemilikan dan hak penyelenggaraan jalan tol ada di tangan pemerintah.

Jalan tol adalah jalan umum dan merupakan bagian dari jaringan jalan bebas hambatan sebagai jalan nasional yang kepada penggunanya dikenakan tarif tol. Jalan tol merupakan bagian dari jalan bebas hambatan pada dasarnya merupakan jalan alternatif dimana disyaratkan harus tersedia jalan umum non tol untuk memberikan pilihan kepada pengguna. Dilihat dari fungsinya, jalan tol memberikan alternatif bagi pelaku perjalanan untuk menghemat waktu tempuh, serta menikmati tingkat pelayanan yang lebih baik dibandingkan dengan menggunakan jalan non tol, keuntungan ini dikompensasikan dengan keharusan mengeluarkan biaya tambahan, dimana penggunaan jalan non-tol dibebaskan dari tarif.(PP No 8 tahun 1990)

Maksud penyelenggaraan jalan tol adalah untuk mewujudkanpemerataan pembangunan dan hasil-hasilnya serta keseimbangan dalam pengembangan wilayah secara adil, dimana pembinaannya memakai dana yang berasal dari masyarakat yakni melalui pembayaran jalan tol. Sedangkan tujuannya adalah untuk meningkatkan efisiensi pelayanan jasa distribusi untuk menunjang pertumbuhan ekonomi di wilayah yang tidak tinggi tingkat perkembangannya (PP No. 8 Tahun 1990).

Adapun definisi lain dari jalan tol atau jalan bebas hambatan yaitu jalan cepat dengan pengendalian jalan masuk sepenuhnya. Pengendalian jalan masuk sepenuhnya atau full control of access berarti bahwa kewenangan mengatur jalan masuk ditujukan untuk mengistimewakan lalu lintas yang bergerak lurus dengan menyediakan hubungan jalan masuk hanya dengan jalan umum tertentu serta dengan melarang penyeberangan sebidang atau hubungan langsung dengan jalan menuju ke rumah-rumah

\section{Program E-toll Card}

E-Toll adalah sebuah kartu elektronik yang digunakan untuk 
melakukan pembayaran masuk jalan tol di sebagian daerah Indonesia. Penggunaan $e$ toll hanya dengan menggunakan kartu yang ditempelkan dan selesai dalam waktu 4 detik saja. Kartu e-toll dikeluarkan oleh PT. Jasa Marga yang bekerjasama dengan Bank Mandiri dan di terapkan pada tahun 2009 di ruas jalan tol tertentu. Teknologi yang digunakan E-Toll card adalah RFID (Radio Frequency Identification) dimana transaksi dapat dilakukan jarak jauh (contactless). Dengan layanan ini pelanggan hanya perlu menempel kartu pada mesin reader contactless yang telah di sediakan, Toll card tidak dibutuhkan PIN atau tanda tangan (Gita PA \& Eva HF, 2016)

Dalam penelitian ini digunakan variabel tunggal yang menggambarkan sebab akibat atas penggunaan e-toll card yaitu variabel efektivitas layanan pada gerbang toll yang ada di Makassar. Untuk mengukur tingkat efektivitas penggunaan e-toll card menggunakan 5 indikator yang dikemukan oleh (Sutrisno, Edy, 2008 ) yaitu pemahaman program, tepat sasaran, tepat waktu, tercapainya tujuan, perubahan nyata.

\section{Efektivitas Pelayanan}

Efektivitas pada dasarnya berhubungan dengan pencapaian tujuan atau target kebijakan (hasil guna). Menurut (Ihyaul, 2009) efektivitas merupakan hubungan antara keluaran dengan tujuan atau sasaran yang harus dicapai. Kegiatan operasional dikatakan efektif apabila proses kegiatan mencapai tujuan dan sasaran akhir kebijakan (spending wisely).

Efektivitas adalah pemanfaatan sumber daya, sarana dan prasarana dalam jumlah tertentu yang ditetapkan sebelumnya untukmenghasilkan sejumlah barang atas jasa kegiatan yang dijalankannya. Efektivitas menunjukan keberhasilan dari segi tercapai tidaknya sasaran yang telah ditetapkannya. Jika hasil kegiatan semakin mendekati sasaran, berarti makin tinggi efektivitasnya (Siagian PS, 2009).

Pengukuran efektivitas merupakan salah satu kinerja bagi pelaksanaan suatu kegiatan yang telah ditetapkan untuk menyajikan informasi tentang seberapa besar pencapaian sasaran atas target. Kemampuan dalam menjalankan tugas dikategorikan efektif apabila suatu rasio yang dicapai mencapai 100\%. Namun, demikian semakin tinggi ratio efektivitas, menggambarkan kemampuan penggunaan biaya semakin baik.

Efektivitas suatu program dapat terjadi ketika terlaksana dengan baik dalam mencapai tujuan sesuai dengan sasaran yang telah ditetapkan sebelumnya. Sebaliknya jika kepuasan pelanggan inigin tercapai maka dapat dilakukan dengan meningkatkan efektivitas guna mencapai harapan pelanggan. (Chryseislw \& Wilma LS, 2019)

Menurut (Jones R \& $\mathrm{M}$. Pendlebury, 2009), efektivitas adalah sukses mencapai suatu tujuan. Oleh sebab itu, efektivitas hanya berhubungan dengan output atau hasil. Suatu hal penting yang harus diperhatikan adalah bahwa derajat efektivitas tidak menyatakan apa-apa tentang berapa besar pengeluaran untuk mencapainya. Jadi, yang menjadi ukurannya adalah hasilnya (output).

Menurut (Sutrisno, E, 2007) pengukuran mengenai pencapaian tujuan efektif atau tidak terhadap suatu program didasarkan pada:

1. Pemahaman program, dilihat sejauh mana masyarakat memahami program tersebut

2. Tepat sasaran, mengukur sejauh mana lembaga berhasil merealisasikan sasaran yang hendak dicapai. 
3. Tepat waktu, factor waktu yang berkaitan dengan layanan yang cepat dan efisien

4. Tercapainya tujuan, merupakan keseluruhan upaya pencapaian tujuan secara keseluruhan

5. Perubahan nyata, ini dapat dilihat jika suatu program memberikan dampak dan perubaha nyata dengan mengetahui kondisi sebelum dan sesudah adanya program tersebut.

\section{Pelayanan Publik}

Salah satu layanan public yang akhir-akhir ini marak di perbincangkan adalah layanan pada gerbang toll dibeberapa kota besar di Indonesia. Pelayanan publik adalah pemberi pelayanan (melayani) keperluan orang atau masyarakat yang mempunyai kepentingan pada organisasi itu sesuai dengan aturan pokok dan tata cara yang ditetapkan (Kurniawan \& Agung, 2008).

Pelayanan dapat dikategorikan efektif apabila masyarakat mendapatkan kemudahan pelayanan dengan prosedur yang singkat, cepat, tepat, dan memuaskan. Penyelenggara pelayanan publik seharusnya melakukan inovasiinovasi terhadap pelayanan yang diberikan kepada masyarakat.

Berdasarkan Keputusan Menteri Pendayagunaan Aparatur Negara No. 63Tahun 2003 tentang pedoman umum penyelenggaraan pelayanan publik dalam (14), standarkualitas pelayanan sekurang-kurangnya meliputi :

a. Prosedur pelayanan yang di lakukan bagi pemberi dan penerima pelayanantermasuk pengaduan.

b. Waktu penyelesaian yang di tetapkan sejak sesaat pengajuan permohonansampai penyelesaian pelayanan termasuk pengaduan.

c. Biaya pelayanan termasuk rinciannya yang ditetapkan dalam proses pemberianpelayanan. d. Produk pelayanan, hasil pelayanan yang akan diterima sesuai denganketentuan yang telahditetapkan.

e. Sarana dan prasarana, penyedia sarana dan prasarana pelayanan yang memadaioleh penyelenggara pelayanan publik.

f. Kompetensi petugas memberi layanan harus ditetapkan dengan tepatberdasarkan pengetahuan, keahlian, keterampilan, sikap dan prilaku yangdibutuhkan.

\section{METODE PENELITIAN}

Menurut (Sugioyono, 2011) metode penelitian merupakan cara ilmiah untuk mendapatkan data dengan tujuan dan kegunaan tertentu. Jenis penelitian bisa di definisikan sebagai pemilihan metode untuk memudahkan para peneliti mengumpulkan data yang sesuai dan tepat sasaran dalam penelitiannya, oleh karena itu kesesuaian dan ketepatan data sangat dipengaruhi oleh jenis penelitian yang diambil.

\section{Waktu dan LokasiPenelitian}

Penelitian ini akan dilaksanakan pada tahun 2018 mulai pada Bulan Januari sampai pada Bulan Desember. Lokasi penelitian bertempat di kota Makassar.

\section{Jenis dan Sumber Data}

Jenis data yang dipergunakan dalam penelitian ini adalah data primer, yaitu data yang diperoleh melalui observasi, wawancara dan kuisioner. Sumber data adalah masyarakat pengguna jalan tol yang menggunakan e-toll card di Makassar. Sementara data sekunder diperoleh dari lembaga keuangan yang menerbitkan e-toll card.

\section{Teknik PengumpulanData}

Teknik pengumpulan data yang 
dilakukan pada penelitian ini observasi atau pengamatan, wawancara dan penyebaran kuisioner terhadap perilaku masyarakat sebagai pengguna jalan tol yang menjadi target sampel dalam penelitian ini.

\section{Populasi danSampel}

Populasi dalam penelitian ini adalah seluruh masyarakat yang menggunakan jasa layanan e-toll card. Sementara teknik pengambilan sampel yang dilakukan dalam penelitian ini adalah purposive sampling. Dengan menggunakan teknik purposive sampling, maka perlu ditentukan kriteria pengguna jalan tol dengan menggunakan e-toll card yang masuk sebagai sampel.

\section{Pengolahan dan AnalisisData}

Pengolahan data yang digunakan dalan penelitian ini adalah spss for windows versi 21. Sementara analisis data menggunakan regresi berganda dengan persamaan sebagai berikut :

$Y=a+b x+\varepsilon$

Dimana :

$$
\begin{aligned}
\mathrm{Y} & =\text { Efektivitas layanan } \\
\mathrm{X} & =\text { E-toll Card } \\
\mathrm{a} & =\text { Konstanta } \\
\mathrm{b} & =\text { Koefisien Regresi } \\
\varepsilon & =\text { errorterm }
\end{aligned}
$$

\section{HASIL DAN PEMBAHASAN}

Penggunaan e-payment pada gerbang tol di Makassar menuai banyak pro dan kontra. Namun pada dasarnya sebagai besar masyakat mendukung penuh adanya program ini. Pada table berikut dapat dilihat pertumbuhan pengguna jalan tol di Makassar.

Tabel 1.Trafic tol

\begin{tabular}{|l|l|}
\hline Tahun & Jumlah pengguna tol \\
\hline
\end{tabular}

\begin{tabular}{|l|l|}
\hline 2014 & 20.295 .532 \\
2015 & 20.889 .614 \\
2016 & 21.411 .447 \\
2017 & 22.897 .089 \\
2018 & 22.804 .812 \\
\hline
\end{tabular}

Sumber : PT. Bosowa Marga Nusantara

Dari tabel diatas dapat dikatakan bahwa pertumbuhan jumlah pengguna tol di Makassar menunjukan jumlah yang signifikan. Pada tahun 2014-2017 masih menggunakan system manual atau non e-payment. Kemudian pada tahun 2018 PT. BMN bekerjasama dengan Bank Indonesia dan lembagalembaga terkait terus melakukan sosialisasi untuk memberikan edukasi kepada masyarakat tentang pentingnya menggunakan e-toll card. Walaupun implementasi dari e-toll card sudah maksimal namun masih banyak masyarakat yang menolak kehadiran $e$ toll card. Namun tantangan ini disambut baik oleh pihak PT. BMN selaku lembaga usaha pengelola jalan tol bekerjasaa dengan Bank Indonesia dan semua user yang ada untuk terus meningkatkan edukasi tentang proses transaksi di jalan tol dengan menggunakan e-toll card

\section{Hasil}

Untuk mengukur tingkat efektivitas layanan dengan menggunakan e-toll card pada semua gerbang tol yang ada di Makassar, maka peneliti menggunakan kuisioner untuk mendapatkan hasil dari apa yang ingin dicapai.

Berdasarkan hasil penyebaran kuisioner terhadap 100 responden yang merupakan pengguna jalan tol dan menggunakan e-toll card sebagai media layanan pembayaran jasa tol di Makassar, maka dapat di uraikan karakteristik responden sebaga berikut : 
a. Karakteristik berdasarkan jenis kelamin.

Karakteristik responden yang diukur berdasarkan jenis kelamin merupakan salah satu bagian penting dalam menilai tingkat efiktivitas dalam layanan di jalan tol. Dari hasil penyebaran kuisioner menunjukkan bahwa jumlah pengguna jalan tol di dominasi oleh wanita yaitu sebesar $51,9 \%$ dan pengguna jalan tol berjenis kelamin pria adalah sebesar $48,1 \%$. Dengan demikian dapat disimpulkan bahwa pengguna jalan tol di Makassar adalah berjenis kelamin wanita.

b. Karakteristik berdasarkan usia

Karakteristik responden yang diukur berdasarkan usia juga bervariasi. Dalam penelitian ini karakteristik responden berdasarkan usia dikelompokkan menjadi:

- Usia 17-25 tahun, dimana kelompok usia ini adalah mereka yang memiiliki pemahaman yang baik tentang layanan jasa dan mampu menyerap dengan cepat segala informasi yang ada. Dan responden dalam kelompok usia ini menunjukan jumlah sebesar $25,9 \%$.

- Usia 26-35 tahun, dimana kelompok usia ini adalah mereka yang memiliki pengalaman yang cukup dalam hal layanan jasa. Dan kelompok responden ini menunjukan hasil sebesar 50,9\%

- Usia< 35 tahun, dimana kelompok usia ini adalah usia puncak dalam hal penerimaan informasi secara cepat. Kelompok responden ini menunjukan hasil sebesar 23,1\%.

Berdasarkan hasil kuisioner dari responden, usia maka dapat disimpulkan bahwa kelompok usia 26-35 tahun yang mayoritas pengguna jalan tol di Makassar.

Dari rekapitulasi seluruh hasil kuisioner menunjukan bahwa persepsi responden tentang penggunaan e-toll card di setiap layanan di gerbang tol yang ada di Makassar secara keseluruhan rata-rata adalah baik atau 3,8 . Persepsi responden dengan nilai tertinggi adalah sebesar 4,2 yang menyatakan bahwa layanan transaksi digerbang tol menggunakan sistem elektronik atau e-toll card merupakan program yang sangat bermanfaat karna dapat menghemat waktu dibandingkan dengan menggunakan uang tunai. Selain itu dengan menggunakan e-toll card dianggap dapat mempercepat proses transaksi dan mengurai kemacetan di gerbang tol. Sedangkan persepsi responden dengan nilai terendah adalah 3,4 adalah lembaga keuangan sebagai penyedia jasa layanan e-toll card dalam memberikan informasi yang jelas dan akurat tentang kelebihan dan kekurangan dari e-toll card.

Untuk meningkatkan penggunaan e-toll card terhadap masyarakat maka dibutuhkan waktu untuk edukasi yang berkesinambungan, karna penggunaan e-toll card ini dinilai memberikan dampak positif bagi pengguna jalan dan bagi perusahaan pengelola jalan tol di Makassar yaitu PT. Bosowa Marga Nusantara. Dari seluruh hasil kuisioner responden menyatakan sangat baik $4,2 \%$.

Agar memudahkan masyarakat dalam layanan tol dengan menggunakan e-toll card tentunya dibutuhkan berbagai sumber informasi untuk mengedukasi masyarakat tentang perkembangan sistem pembayaran saat ini tak terkecuali di gerbang tol.

Sosialisasi kemnafaatan program sangat penting dilakukan secara berkesinambungan demi meningkatkan mutu layanan public. Dari keseluruhan 
hasil kuisioner yang ada menunjukan bahwa Informasi tentang program penggunaan e-toll card dapat diperoleh di mana saja (website, media online, dan media cetak) sebesar 3,8\% atau cukup artinya pihak pengelola jalan tol perlu lebih meningkatkan sosialisasi tentang penggunaan jalan tol dengan menggunakan e-toll card selain dapat mengurangi kemacetan program ini juga merupakan standar system pelayanan berbasis digital. Pengelola jalan di Makassar dalam hal ini adalah PT Bosowa Marga Nusantara diharapkan dapat memberikan informasi terkait pentingnya penggunaan jalan tol di semua media yang ada dan mudah dilihat oleh masyarakat.

$$
\text { Sebagaimana yang telah }
$$

dikemukan sebelumnya bahwa tujuan dari penggunaan e-toll card ini adalah untuk mendukung GNNT atau gerakan nasional no tunai yang di cangkan oleh Bank Indonesia dan didukung oleh banyak pihak salah satunya adalah pengelolaan transasksi di gerbang toll dengan menggunakan e-payment. Respon positif ini ditanggapi oleh responden dengan penilaian setuju dan sangat setuju atau sebesar $76 \%$. Untuk lebih meningkatkan mutu layanan digerbang tol maka PT Bosowa Marga Nusantara selaku pengelola jalan tol yang ada di Makassar terus melakukan sosialisasi dan edukasi agar mencapai target implemetasi dalam hal efektivitas layanan di gerbang tol dengan menggunakan e-toll card.

Dari semua kegiatan yang telah dilakukan tentunya diikuti oleh pemantuan kembali atas program yang telah dibuat, apakah sesuai dengan standar atau masih ada hal hal lain yang perlu dibenahi. Utnuk mengetahui hal tersebut PT. Bosowa Marga Nusantara menyediakan loket-loket khusus untuk melayani masyarakat pengguna jalan tol apabila memiliki keluhan terkait penggunaan e-toll card. Hasil kuisoner terkait pemantuan program ini di peroleh hasil tertinggi yaitu $44,9 \%$ atau sangat setuju. Dengan demikian masyarakat merasa terbantu dengan adanya loket layanan pengaduan tersebut.

\section{Uji Reliabilitas}

Untuk mnegetahui hasil dalam sebuah penelitian, maka terlebih dahulu dilakukan uji reliabilitas untuk mengukur variabel penelitian walaupun peneletian tersebut dilakukan berulangulang dengan kuisioner yang sama. Uji reliabilitas ini dapat dilihat konsistensi instrument yang digunakan dari waktu ke waktu sehingga data responden dapat diandalkan sebagai tolak ukru dalam mengambil keputusan.

Dalam bukunya V. Wiratna Sujarweni, 2014 menjelaskan bahwa uji reliabilitas dapat dilakukan secara bersama-sama terhadap seluruh item pertanyaan dalam kuisioner. Dan yang menjadi dasar pengambilan keputusan dalam uji reliabilitis ini adalah dengan menggunakan metode cronbach's alpha dengan asumsi :

- Jika nilai cronbach's alpha > 0,60 maka kuisioner/angket yang digunakan dinyatakan reliabel/konsisten

- Dan jika nilai cronbach's alpha < 0,60 maka kuisioner yang digunakan dalam penelitian dianggap tidak reliabel atau konsisten

Berdasarkan tabel uji reliabilitas yang dilakukan dengan menggunakan metode cronbach's alpha terhadap 100 respon dengan menggunan 16 item dalam kuisioner untuk mengukur tingkat efektivitas layanan di gerbang tol Makassar, maka diperoleh hasil cronbach's alpha sebesar 0,91. Dapat disimpulkan bahwa semua pertanyaan pada instrument penelitian ini adalah reliable atau konsisten

Tabel 2.Reliability Statistics 


\begin{tabular}{|l|l|}
\hline $\begin{array}{l}\text { Cronbach's } \\
\text { Alpha }\end{array}$ & N of Items \\
\hline, 919 & 16 \\
\hline
\end{tabular}

Sumber:olah spss 21

\section{Uji Validitas}

Untuk mengetahui tingkat kevalidan atau kesesuaian angket/kuisioner yang digunakan peneliti dalam memperoleh data dari responden atau sampe penelitian. Selain itu uji validitas ini juga bermaksud untuk menghubungkan atau mengkoneksikanantar masing-masing skor item atau soal dengan skor total yang diperoleh dari jawaban responden atau kuisioner yang telah disebar.

Dengan menggunakan tingkat signifikan probabilitas sebesar 0,05, maka yang menjadi dasar pengambilan keputusan ini adalah membandingkan nilai $r$ hitung dan $r$ tabel. Berdasarkan hasil uji validitas melalui aplikasi spss versi 21 ditemukan hasil bahwa dari 16 item pertanyaan dalam kuisioner yang telah dibagikan kepada 100 responden pengguna jalan tol adalah $r$ hitung sebesar 1,0 dan $\mathrm{r}$ tabel sebesar 0,4 artinya $\mathrm{r}$ hitung $>\mathrm{r}$ tabel maka keseluruhan item yang digunakan dalam mengukur tingkat efektivitas layanan di gerbang tol dinyatakan valid.

\section{Uji Regresi Linier Sederhana}

Koefisien Nilai Regresi

Pada umumnya persamaan regresi adalah $\mathrm{Y}=\mathrm{a}+\mathrm{bX}$, maka untuk mengetahui nilai koefisien tersebut dapat dilihat pada tabel sebagai berikut :

Tabel 3 : Coefficients ${ }^{\mathrm{a}}$

\begin{tabular}{|c|c|c|c|c|c|c|}
\hline \multirow{2}{*}{\multicolumn{2}{|c|}{ Model }} & \multicolumn{2}{|c|}{ Unstandardized Coefficients } & \multirow{2}{*}{\begin{tabular}{|l} 
Standardized \\
Coefficients
\end{tabular}} & \multirow[b]{2}{*}{$\mathrm{T}$} & \multirow[b]{2}{*}{ Sig } \\
\hline & & $\mathrm{B}$ & Std. Error & & & \\
\hline \multirow[t]{2}{*}{1} & (Constant) & 59,782 & 2,095 & & 28,540 &, 000 \\
\hline & Pengunaan e-toll &, 059 & 036 &, 164 & 1,648 &, 102 \\
\hline
\end{tabular}

a. Dependent Variable: Efektivitas layanan

Sumber : olah data spss

Nilai constant (a) sebesar 59,782 artinya bahwa jika nilai $\mathrm{X}$ (penggunaan e-toll) sama dengan nol maka nilai Y ( efektivitas layanan ) sama dengan 59,782Nilai koefisien regresi untuk $\mathrm{X}$ (penggunaan etoll) adalah 0,059 yang artinya setiap kenaikan nilai variabel $\mathrm{X}$ sebesar satu satuan akan menyebabkan kenaikan nilai $Y$ (efektivitas layanan) sebesar 0,059

\section{Analaisis koefisien korelasi}

Untuk melihat besarnya pengaruh variable $X$ (penggunaan e-toll) terhadap variable Y ( efektivitas layanan) maka dapat dianalisis melalui tabel berikut ini :
Tabel 4 : Model Summary

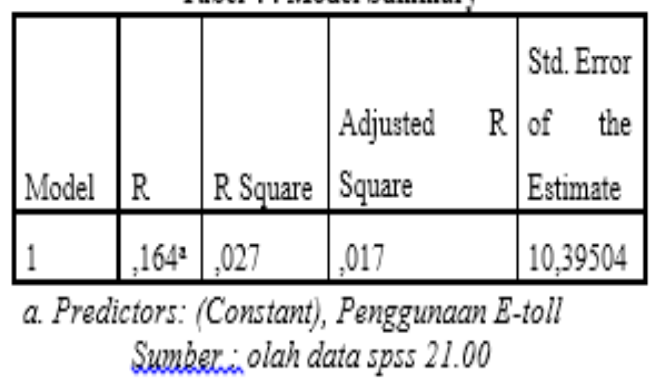

Dari tabel diatas dapat dilihat nilai $\mathrm{R}$ square yaitu sebesar 0,027 yang artinya secara statistik hubungan variable X dan Y dikatakan kurang kuat. Analisis ini diperlukan untuk mengukur kontribusi variable $\mathrm{X}$ terhadap variable 
$\mathrm{Y}$ atau $\mathrm{KP}=\mathrm{r}^{2} \times 100 \%$, maka $0,164^{2} \mathrm{x}$ $100 \%=0,29$ atau $29 \%$.

Berdasarkan hasil perhitungan tersebut maka dapat dikatakan bahwa kontribusi atau pengaruh variable $\mathrm{X}$ atau penggunaan e-toll dengan variable Y efektivitas layanan di gerbang toll Makassar sebesar 29\% atau cukup kuat sedangkan sisanya sebesar $71 \%$ dipengaruhi oleh faktor lain diluar penelitian ini.

\section{Uji hipotesis}

Uji hipotesis atau uji regresi yang dilakukan pada dasarnya untuk memastikan apakah variable tersebut memiliki pengaruh yang signifikan atau tidak. Dengan menggunakan tingkat signifikan sebesar 0,05 maka dapat dilakukan dengan membandingkan $t$ table dan $t_{\text {hitung. }}$.

Hubungan positif antara pengggunaan produk e-toll card dengan efektivitas layanan di gerbang toll Makassar pada level (a) adalah 0,05 dan df sebesar 100 maka $t_{\text {tabel }}=1,40$. Dari uji hipotesis yang dilakukan maka $t_{\text {hitung }}>t_{\text {tabel }}$ atau 1,64>1,40 artinya $\mathrm{H}_{0}$ ditolak dan $\mathrm{H}_{\mathrm{a}}$ diterima. Maka ada hubungan positif dari penggunaan e-toll card(variable $\mathrm{X}$ ) terhadap efektivitas layanan(variable Y) di gerbang tol Makassar

\section{KESIMPULAN}

Berdasarkan uraian diatas, maka dalam penelitian ini dapat disimpulkan bahwa layanan di gerbang tol yang ada di Makassar dengan menggunakan e-toll card berpengaruh sigfinifikan terhadap efektifitas layanan. Besaran pengaruh ini ditunjukkan dengan hasil olah data yaitu sebesar $29 \%$ atau dapat katakana berpengaruh cukup kuat.

Hal-hal yang mendasari keputusan ini, dilihat pada keseluruahan indikator dalam menilai efektivitas layanan di gerbang tol Makassar yaitu pemahaman masyakarat mengenai program $e$ payment, tepat waktu, tetap sasaran, tujuan dan perubahan nyata atas program yang telah dilakukan. Dari hasil kuisioner yang telah di sebar ke 100 responden yang merupakan pengguna e-toll card, indikator ini memberikan respon positif.

Tak jauh berbeda dengan hasil interview peneliti dengan perusahan pengelola jalan tol di Makassar yaitu PT. Bosowa Marga Nusantara yang mengemukan bahwa pihaknya terus melakukan sosialiasi tentang pentingnya menggunakan e-toll card di gerbang tol Makassar dengan mengandeng beberapa pihak-pihak terkait seperti instansi pemerintahan maupun swasta serta melibatkan satuan pengamanan di gerbang tol demi kelancaran berkendara di jalan tol. Walaupun berdasarkan survei internal yang dilakukan oleh PT BMN menunjukkan implementasi penggunaan e-payment di gerbang tol sebesar $90-100 \%$ per tahun 2018. Capaian ini tentunya tidak lepas pihakpihak yang kontra atau tidak setuju dengan adanya program ini.

\section{SARAN}

Saran yang dapat disampaikan oleh peneliti yaitu

1. Pentingnya melakukan edukasi yang berkesinambungan agar informasi-informasi positif dapat disebarkan demi kepentingan dan kenyamanan dalam memudahkan transaksi dijalan tol.

2. Dengan adanya penelitian ini pihak pengelola jalan tol di Makassar berharap bahwa pihak akademisi mampu mengedukasi masyarakat tentang pentingnya program ini.

3. Pada penelitian berikutnya diharapkan mampu mengembangkan variable-variabel penting lainnya dalam mengukur efektivitas layanan di gerbang tol dengan 
menggunakan e-toll card. Variable yang dapat dikembangkan selanjutnya adalah mengenai loyalitas masyarakat sebagai pengguna jalan dengan menggunakan sistem digital

\section{ACKNOWLEDGEMENT}

Penelitian ini tentu tidak dapat terlaksana atau diselesaikan dengan tepat waktu tanpa dukungan dan partisipasi dari berbagai pihak, utamanya dari pihak yang telah menghibahkan dana penelitian. Untuk itu peneliti mengucapkan terima kasih yang tak terhingga kepada Kementerian Riset Teknologi dan Pendidikan Tinggi yang telah mempercaya peneliti dalam melakukan penelitian ini.

\section{DAFTAR PUSTAKA}

Sabrina O. Sihombing, 2015, Prediksi Penggunaan Aktual E-Toll Card dengan Metode Pendekatan Persamaan Struktural, Universitas Pelita Harapan.

Undang-undang no 13 tahun 1980 tentang jalan toll.

Peraturan pemerintah no 8 tahun 1990 tentang jalan tol.

Gita P.A, Eva H.F, 2016, Efektivitas Elektronik Toll (E-Toll) PT Jasa Marga Surabaya, Universitas Negeri Surabaya.

Sutrisno, Edy, 2008, Manajemen Sumber Daya Manusia, Jakarta: Kencana.

Ihyaul, 2009, Prospek Otonomi Daerah dan Perekonomian Indonesia. BPFE, UBM Yogyakarta.

Siagian, P. Sondang, 2009. Organisasi Kepemimpinan dan Perilaku
Organisasi, Gunung Agung, Jakarta.

Jones, R dan M. Pendlebury. 2009. Public Sector Accounting. $5^{\text {th }}$ Edition. Pitman Publishing, London.

Kurniawan, Agung. 2008. Transformasi Pelayanan Publik. Yogyakarta: Pembaruan.

Sugiyono. 2011. Metode Penelitian Kualitatif dan Kuantitatif Cetakan ke 11. Bandung: CV Alfabeta.

Wachidatus S, Novi M. 2018. Use of etoll Cards : Satisfied Consumers? Jurnal Manajemen Motivasi 14 73-79, Fakultas Ekonomi Universitas Negeri Surabaya.

Herry TZ, Sigit PH dan Hadi R. 2014. Atribut Pelayanana Jalan Tol Dalam Peningkatan Kualitas Berkendara (Studi Kasus : Jalan Tol Makassar). Direktorat Jendral Bina Marga, Kementrian Pekerjaan Umum.

Sutrisno E. 2007. Budaya Organisasi, Jakarta. Fajar Interpratama Mandiri.

Sabariah. 2015. Pengaruh Kualitas Layanan Terhadap Kepuasan Pelanggan Rumah Tangga pada PT. PLN (Persero) Rayon Samarinda ULU. E-Journal Ilmu Administrasi Negara.

Chryseis IW, Wilma LS. 2019. Pengaruh E-Toll Card Mandiri dan Efektivitasnya terhadap Kepuasan Pelanggan E-toll Card di Surabaya. Program Studi Manajemen. Universitas Kristen Petra. 
V. Wiratna Sujarweni, 2014. SPSS

untuk Penelitian, Yogyakarta, Pustaka Baru. 